\title{
Conceptualising climate change archaeology
}

\author{
Robert Van de Noort*
}

\section{Introduction}

Archaeology claims a long tradition, going back to the middle of the nineteenth century, of undertaking both palaeoclimate research and studies on the impact of past climate change on human communities (Trigger 1996: 130-38). Such research ought to be making a significant contribution to modern climate change debates, such as those led by the Intergovernmental Panel on Climate Change (IPCC); but in practice this rarely happens (e.g. McIntosh et al. 2000). This paper will attempt to conceptualise a 'climate change archaeology', which is defined here as the contribution of archaeological research to modern climate change debates (cf. Mitchell 2008). Irrespective of whether climate change poses the greatest challenge in the twenty-first century or whether it is just one of many challenges facing humanity (cf. Rowland 2010), the absence of an archaeological voice diminishes the relevance and impact of the debate as a whole.

This paper will consider the current relationship between climate change research and archaeology, noting that an evidence base for the impacts of past climate change, and the responses of communities, is almost entirely missing from the agenda. An argument will then be made that archaeology is well placed to enhance the socio-ecological resilience of communities and their adaptive capacity to climate change through the study of past pathways to adaptation. Finally, the concepts of climate change archaeology and the contribution it can make to current debates will be illustrated in a case-study, focused on the North Sea.

\section{Climate change research and archaeology}

The IPCC was created by the World Meteorological Organisation and the United Nations Environment Program in 1988. The United Nations' General Assembly defined the task of the IPCC as follows:

'to prepare a comprehensive review and recommendations with respect to the state of knowledge of the science of climate change; social and economic impact of climate change, possible response strategies and elements for inclusion in a possible future international convention on climate’ (UN General Assembly Resolution 43/53; 6 December 1988).

The IPCC does not undertake primary research itself, but carries out meta-analyses of published studies and presents these in its 'assessment reports'. To date, the IPCC has

Department of Archaeology, University of Exeter, Laver Building, North Park Road, Exeter EX4 4QE, UK (Email:r.van-de-noort@ex.ac.uk) 
delivered four such reports, and the Fourth assessment report (AR4) was awarded the Nobel Peace Prize. These assessment reports present the results of three different working groups. Working Group I is concerned with the scientific basis of climate change; the chapters on palaeoclimate provide a long-term context for the projections of future climate change, as well as distinguishing between its natural and anthropogenic components. Working Group II focuses on the impact on the environment and people's adaptation to climate change. Working Group III concentrates on the mitigation of the effects of fossil-carbon fuelled climate change. Many states have developed national assessments, agendas and policies based on the IPCC findings to consider what modern climate change means for them, such as the Stern review on the economics of climate change (Stern 2006).

In $A R 4$, it was noted that there is unequivocal evidence that the global atmospheric concentration of Green House Gases (GHGs) has increased since AD 1750 'as a result of human activities' (Bernstein et al. 2007: 37). Atmospheric concentrations of carbon dioxide $\left(\mathrm{CO}_{2}\right)$ and methane $\left(\mathrm{CH}_{4}\right)$ are higher today than at any time in the last 650000 years. Current concentrations of nitrous oxide $\left(\mathrm{N}_{2} \mathrm{O}\right)$ are very likely unprecedented for the last 16000 years. The recent increase in $\mathrm{CO}_{2}$ is due primarily to the burning of fossil fuels; the increase in $\mathrm{CH}_{4}$ to agriculture and fossil fuel use and the increase in $\mathrm{N}_{2} \mathrm{O}$ primarily to agriculture (Bernstein et al. 2007: 37). Higher concentrations of these wellmixed GHGs result in increased radiative forcing and accelerated global warming (Bernstein et al. 2007: 37). Whilst the palaeoclimate studies in the IPCC reports provide long-term retrospective contexts to modern and predicted climate change, the field of palaeoclimate research has in itself become increasingly scientifically rigorous. The most significant advance is a more confident understanding of relationships between regional climate research and global changes at a centennial resolution, through the meta-analysis of studies from around the world.

Where archaeological projects integrate palaeoclimatological or palaeoenvironmental research, the results of these aspects of research may have been included in the national and international meta-analyses that feed into the IPCC's assessment reports but, as a rule, this is not the case for the impacts of climate and environmental change on past communities (cf. Parry et al. 2007). The comparatively small-scale nature of archaeological research poses a particular problem. In mistakenly assuming that examples of local and regional climate change are reflections of change at a global scale, archaeological studies have sometimes concluded that in the long history of humankind modern climate change is 'nothing new' (Jansen et al. 2007). Such arguments must be countered by an explicit recognition that significant local variation exists within global trends.

Alongside historians and anthropologists, archaeologists have argued that communities' social memories contain reservoirs of knowledge about past climate change and human adaptation, providing information on a temporal and geographical scale rarely available to climate change scientists (e.g. McIntosh et al. 2000: 24-5). However, much of this kind of evidence lacks the required accuracy — in terms of dating, geographical location, or the exact nature of the climate change event or adaptation described — for it to be included in any of the large climate change models.

The AR4 section Impacts, adaption, vulnerability (Parry et al. 2007) considers the adaptation of communities to the impacts of climate change, which the IPCC defines 
as 'initiatives and measures to reduce the vulnerability of natural and human systems against actual or expected climate change effects' (Bernstein et al. 2007: 76). It recognises that the 'adaptive capacity' of societies is 'intimately connected to social and economic development, but is not evenly distributed across and within societies' (Bernstein et al. 2007: 56). Unlike the scientific basis, this aspect of the climate change report offers no (retrospective) long-term evidence base, and contains no references to archaeological or historical studies. It could be said that the work by the IPCC, together with associated literature at national levels, presents something of a paradox. Whilst the reports have strong foundations in palaeoclimate research (Jansen et al. 2007), the role of past human adaptations to climate change - the diversity of which would contribute to an understanding of how humanity can adapt to climate change today - remains understated (Parry et al. 2007).

Within the archaeological community, there is a consensus that humanity's past relationship with climate change is a source of potentially crucial information, especially at the local or 'human' level. Archaeologists have argued, for example, that they 'can contribute unique insights into the national debate [on climate change], and place the changes happening now into the long story of how humans have adapted to their changing climate over the millennia' (Council for British Archaeology 2007). A number of recent archaeological studies have placed the modern climate change debate in such longer-term perspectives (e.g. Burroughs 2005; Fagan 2008).

Many archaeologists would argue that the potentially most meaningful contribution of archaeology to modern climate change debates lies in the study of the interrelationships between the impact of climate change and the adaptation by communities. In this respect, it is pertinent to remember that the Stern (2006: iv) review noted that 'a radical change in the physical geography of the world must have powerful implications for the human geography where people live, and how they live their lives. It is in the understanding of the interrelationship between the physical and the human world that the evidence base of the IPCC is at its weakest. However, if there are any 'lessons' to be learned from archaeology, these are not about 'if' or 'how' particular human groups adapted to climate change events or developments at a specific place and time in the past; such an emphasis would fail to recognise the unique nature of modern climate change. Instead, these lessons should be about the pathways followed by communities in their adaptation to climate change, and the positive and negative feedbacks that ensued. Past examples would thus inform the construction of adaptive capacities in modern societies dealing with rapid climate change.

Such pathways concern the interrelated environmental, socio-economical and cognitive aspects of living with climate change. They correspond to the 'resilience' perspective in socio-ecological systems analysis (Holling 1973). Originating from ecology, the concept of resilience recognises the long-standing interaction between people and their environment in a myriad ways. It emphasises 'non-linear dynamics, thresholds, uncertainty and surprise, how periods of gradual change interplay with periods of rapid change and how such dynamics interact across temporal and spatial scales' (Folke 2006: 253). Social memory may fall short as a concept or source of archaeological information in understanding climate change itself, but in the face of rapid climate change it can help to build the resilience of communities (Van der Leeuw 2000). 
Adaptation to climate change is exemplified by how communities have dealt with the loss of land due to rising sea levels. For developing countries, the Stern (2006: vii-viii) review notes that sea level rise will result in major economic damage; it also foresees significant social upheaval, migration, innovation and conflict. Equally, sea level change will result in the alteration of characteristic regional landscapes, and the loss of ancient and not-so-ancient monuments such as churches and churchyards. These changes represent, in effect, an assault on people's sense of place and social identity.

How people have responded to such alterations and losses in the past is a theme that has been investigated by archaeologists (e.g. Scarre 2002; Turney \& Brown 2007; Van de Noort 2011). Examples other than sea level change of broad themes through which archaeology can reinforce humanity's resilience to impacts of modern climate change include the nature and volume of migrations; changes in landscapes, especially the regional disappearance of established flora and fauna and the arrival of new species; changes in agricultural production, consumption and subsistence and the impact of climate change on social identities. It would be foolish to suggest that archaeological research alone can produce the reinforcement of human resilience sufficient to deal with climate change. However, the unique archaeological perspective should be able to offer different insights if it is presented in a language that is understood by climate change scientists.

\section{A conceptual framework for 'climate change archaeology'}

In the final paragraphs of a recent paper that critically contemplates the role of archaeology in the context of modern climate change, Peter Mitchell (2008: 1100) considers the challenge that climate change holds for the theoretical framework of archaeological research. He notes that we must adopt a commitment to 'thinking about human societies within an ecological framework [that] does not require a view of the past that is wholly or simply one of climatic or environmental determinism' and we must 'retain a sense of human agency and empowerment when interpreting the past, structuring debates and reaching decisions about what to do.' These thoughts provide the starting point for the development of a conceptual framework for climate change archaeology.

Within archaeological research, the ascribing of a (direct or indirect) significant role to climate change in the human past is highly dependent on the theoretical stance taken. Thus, archaeologists working with an (environmental) functional approach (Trigger 1996: 314-85), have emphasised the profound, and often deterministic, impacts of climate and environmental change on human behaviour (e.g. Clark 1936; Childe 1958; Butzer 1972; but also 'neo-deterministic' studies, e.g. Hodell et al. 1995; deMonocal 2001). Early proponents of the New Archaeology or processual archaeology (Trigger 1996: 302-444), understood the concept of cultural evolution as the cultural adaptation to climate and environmental change (e.g. White 1959; Binford 1968), and thus retained a clear role for climate change. The importance of ecological change has remained strong, despite modifications, and there are many recent studies of how past civilisations adapted to such change (e.g. Yu et al. 2000; Turney et al. 2006). Proponents of post-processual archaeology, however, adopted human agency as the principal means by which societal change was achieved (e.g. Hodder 1986; cf. Trigger 1996: 444-83). Whilst not necessarily seeking to deny (past) climate change, their 
work renders its role effectively invisible (e.g. Hodder 1990; Tilley 1994). A conceptual framework for climate change archaeology should seek not to deny the progress made through these theoretical debates, but rather to develop an approach that fully recognises that on a peopled earth, communities and their environment are interconnected in myriad ways. This resonates with concepts used in modern climate change research, and also with a number of archaeological, anthropological and ecological studies that have sought to put communities and their resilience back into debates on environmental and climate change (e.g. Crumley 1994; Van der Leeuw 2000; Gamble et al. 2004; Hornborg \& Crumley 2007; McAnay \& Yoffee 2010).

Climate scientists employ frameworks such as 'coupled human-earth systems models' (e.g. Cox et al. 2000), which encompass the already known connections whilst leaving space for new ones to emerge. Within these models, there is space for feedback mechanisms of the consequences - both intended and unforeseen - of human adaptation to change. A useful conceptualisation is offered by the IPCC's schematic framework 'representing anthropogenic drivers, impacts of and responses to climate change, and their linkages' presented in the AR4 synthesis report (Bernstein et al. 2007: 26). A slightly amended version is given here as Figure 1. This schematic framework shows the interrelationships between earth systems and human systems. It explicitly acknowledges that within long-term perspectives (natural) climate change and (human) socio-economic developments are interrelated, and both can be prime drivers of change. Climate change impacts on the environment, which in turn affects socio-economic development, either directly or through communities' adaptation to climate change and its impacts, just as socio-economic development impacts on the environment and produces climate process drivers. The framework also expresses the recognition of the operation of feedback mechanisms which provide interactive connections between the different parts, with both positive and negative feedbacks in operation - i.e. those impacts and adaptations that reinforce climate change trends, along with those that weaken these trends.

The framework offers an example of conceptualising a climate change archaeology that interconnects people and communities entirely within the landscape they inhabit - with or without the separation of the peopled earth into earth and human systems. It recognises that climate change has direct impacts on humans, and that it leads indirectly to adaptations within societies to climate and environmental change. Importantly, it is a framework that recognises the importance of human agency in understanding how people change themselves, their communities and their environment. Indeed, the IPCC is now convinced that modern climate change is driven by human agency. The impact of human agency on the climate may be of much greater age than has previously been believed, as argued for example by William Ruddiman (2003) whose meta-analysis of mid-Holocene climate change studies indicates that early agriculture may have been changing the climate for 5000 years or more, to the point that a post-Holocene glacial period was postponed by the onset of agriculture.

Interestingly, this framework implies that the principal theoretical strands in archaeology are, as far as their outlook on the interaction between climate/environment and societies is concerned, complementary rather than oppositional. The framework acknowledges that climate change alters environments and people's health and subsistence directly, something that is a central aspect of environmental functionalism. It also reflects the essence of 


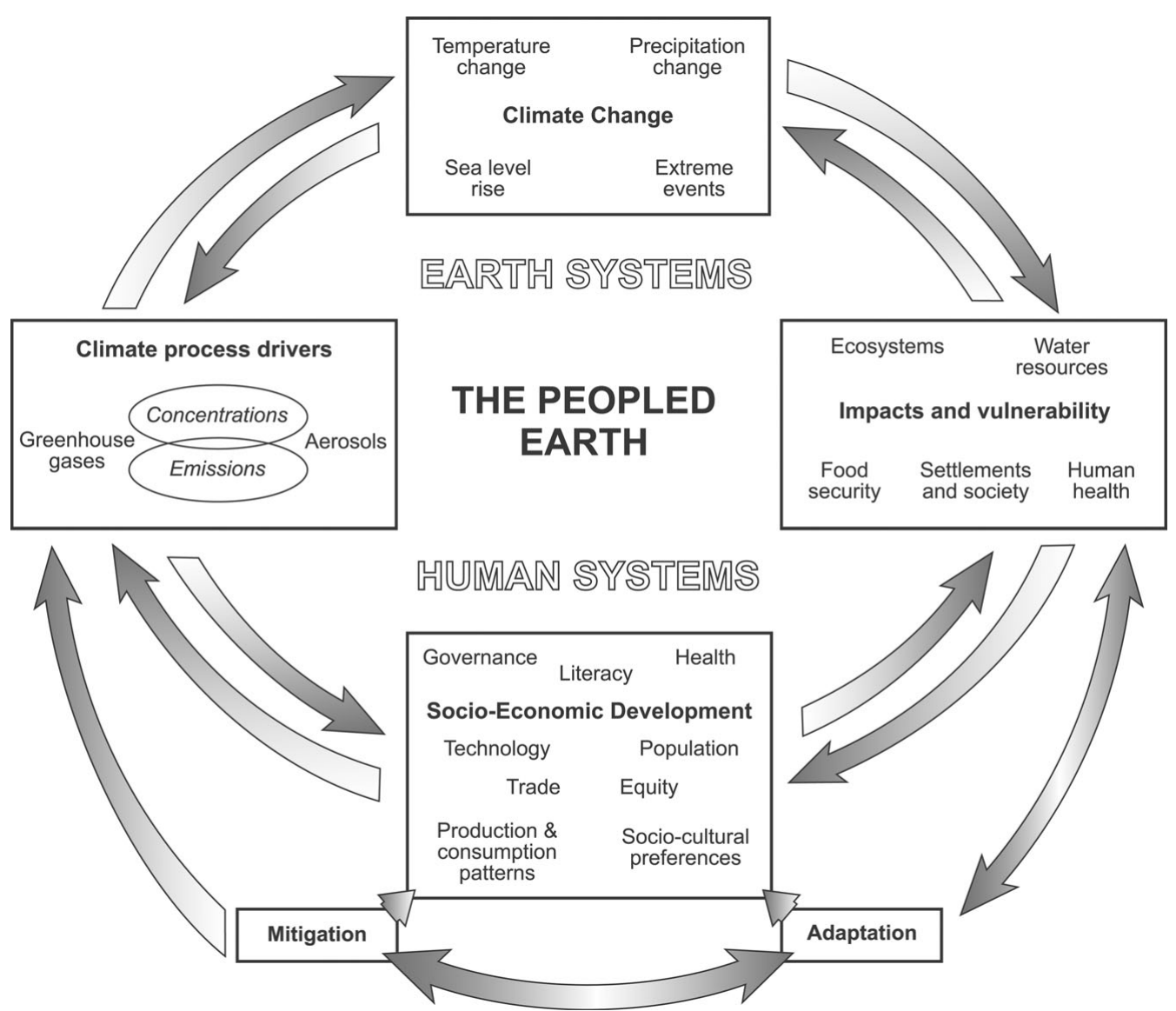

Figure 1. The interrelationship of climate change and cultural change (adapted from Bernstein et al. 2007: 26).

processual thinking, in that cultural adaptation to climate and environmental change is recognised. Finally, it accommodates post-processual concepts of the importance of human agency in cultural processes and its impact on landscapes, environments and, ultimately, climate itself.

Obviously, we need to bear in mind that climate and environmental change were never the only changes faced by communities in the past, and should not be regarded as the 'default' setting for explaining past cultural changes. Societies also had to adapt to internal and external political, economic, social, technological and religious changes, many of them unconnected to climate or environmental change. However, climate change would almost certainly have had an impact on political, economic, social, technological and possibly religious practices, and it is timely to recognise this fully in archaeological research.

\section{A case study: adapting to sea level rise in the North Sea}

Conceptualising the climate change archaeology of the North Sea illustrates the direct impacts of climate change on environment and communities. These impacts include the 
retreat of the ice sheets and post-glacial and Holocene sea level change, which forced communities to change their migratory paths and modes of subsistence, and, following the submergence in the middle Holocene of the North Sea Plain and its islands such as Dogger Bank and Brown Bank, to retreat to the higher grounds of modern Britain and continental Europe (Coles 1998). Climate change had, and continues to have, a direct impact on North Sea ecosystems. For example, the strength of the North Atlantic Current drives changes in North Sea salinity, which in turn impacts on the fish stock and the presence of shellfish (Weijerman et al. 2005), determining their availability - well recorded in archaeological research — as a resource to coastal communities (e.g. Andersen 1995).

Examples of adaptation to the environmental impacts of climate change include the utilisation of the saltmarshes. When sea level rise slowed down around $3000 \mathrm{cal} \mathrm{BC}$, extensive saltmarshes developed in the southern part of the North Sea. These formed where the rate of deposition of fine sediment supplied by the rivers flowing into the North Sea outpaced relative sea level rise (taking into account isostatic and eustatic movements [Shennan \& Horton 2002]). Coastal communities adapted to these new conditions, and the saltmarshes became valued grazing grounds for cattle and sheep from around c. $1500 \mathrm{cal} \mathrm{BC}$ and for the next three millennia (e.g. Van de Noort 2004). A particular adaptation to these new landscapes is found in the Wadden Sea, where stockbreeding was undertaken between 500 cal BC and cal AD 1000 from farms and villages based on the artificial mounds known as 'terps' (Meier 2004). This form of adaptation optimised the economic value of saltmarshes whilst leaving the fragile coastal ecology unharmed.

The importance of human agency in people's reactions to rising sea levels and land loss is evident in these examples. After all, living by the coast is in itself a matter of exercising agency: coastal communities could have decided to move inland rather than adapt to new conditions created by the impact of climate change. Communities can also be seen exercising their agency in the construction of embankments or dikes. The oldest dikes are of late Iron Age or Roman date, but the main period of dike construction commenced in the ninth century AD in south-east England and in the eleventh century AD on the continental North Sea coast (Rippon 2000). The long-term effects of taking land from the sea include the extension of arable land, leading to population increase: many coastal lowlands around the North Sea today have population densities that are amongst the highest in the world, and higher GHG emissions in these locations are themselves a contributory factor in the process of climate change.

Holocene sea level rise resulted in the loss of coastal landscapes that had been socialised by previous generations, and several archaeologists have studied how people in the past adapted to such changes. These studies demonstrate, for example, the ritual significance of newly formed islands (e.g. Scarre 2002), the materialisation of new monuments such as Flag Fen and 'Seahenge' and the emergence of ritual practices that relate directly to the changing coastal landscape, including the deposition of polished stone axes, bronze tools and weapons in the transgressive wetlands (Van de Noort 2011). Aspects of national social identity, such as 'British islandness' and 'the Dutch fight against the sea' are also shown to have been influenced by people's adaptations to change (Zwart 2003). Coastal communities' interaction with relative sea level rise and land loss created a 
hybrid understanding of the land-sea interface, in which the sea was frequently attributed forms of agency that helped communities to understand their loss (Van de Noort 2011).

Climate change archaeology explains the operation of certain feedback mechanisms that have gone largely unnoticed in climate change science. One such mechanism concerns the regional variability of marine transgressions and regressions and its impact on marine ecology. Regional variability is partly determined by the input of sediments through the rivers that have their confluence in the North Sea. Sediment input, however, has been modified by human action, for example through deforestation and the expansion and intensification of arable agriculture from the Neolithic onwards, or the construction of dikes and barriers in the Middle Ages which restricted the outflow of sediments into the deltas (Lotze et al. 2005). Another feedback mechanism is that resulting from coastal management practices and methods. For example, the management of grazing land and rabbit warrens in the late Middle Ages and early modern period contributed to the maintenance of extensive dune systems which protected the hinterland against sea level rise (Beekman 2007).

In summary, the climate change archaeology of the North Sea provides an evidence base of human adaptation to climate and environmental change over a period in excess of 10000 years. It offers knowledge and understanding of the environment, and of the interaction of communities with changing conditions, on a human scale frequently overlooked by climate change scientists. It also provides insights into how previous generations coped technically, economically and emotionally with sea level rise and land loss. Such an understanding offers potential for strengthening people's adaptive capacity and increasing their resilience in dealing with losses suffered as a result of sea level change over the next 20,50 or 80 years. And whilst archaeology will certainly not resolve the impact of climate change on the communities living around the North Sea, it can offer some surprising insight from the past, such as the potential use of newly created saltmarshes as grazing grounds, or the usefulness of rabbits in dune protection.

\section{Conclusion}

This paper has sought to develop a framework for archaeologists to contribute actively and constructively to modern climate change debates. Whilst palaeoclimate evidence forms the bedrock for the scientific assessment of modern climate change, a retrospective evidence base for the impacts of climate change, and for communities' responses, is almost entirely missing. To address this paradox a new concept of climate change archaeology is presented. By offering long-term perspectives on human interrelationships with climate change, archaeology is well placed to enhance an understanding of the socio-ecological resilience of communities and their adaptive capacity. This would appear to be archaeology's chief contribution to the climate change debate. Furthermore, the different theoretical strands in archaeology are not in opposition when it comes to explaining the diverse 
connections between climate, environment, landscape and people, but are seen to be complementary.

\section{Acknowledgements}

I thank Peter Mitchell, Brian Fagan, Chris Turney, Jess Collins and Michael J. Rowland for their constructive comments and suggestions.

\section{References}

ANDERSEN, S.H. 1995. Coastal adaptation and marine exploitation in Late Mesolithic Denmark — with special emphasis on the Limfjord region, in A. Fisher (ed.) Man and sea in the Mesolithic: coastal settlement above and below present sea level. Proceedings of the International Symposium, Kalundborg, Denmark 1993 (Oxbow monograph 53): 41-66. Oxford: Oxbow.

BeEkMan, F. 2007. De Kop van Schouwen onder het zand. Utrecht: Matrijs.

Bernstein, L., P. Bosch, O. Canziani, Z. Chen, R. Christ, O. Davidson, W. Hare, S. HuQ, D. Karoly, V. Kattsov, Z. KundzeWicz, J. Liu, U. Lohmann, M. Manning, T. Matsuno, B. Menne, B. Metz, M. Mirza, N. Nicholls, L. Nurse, P. Pachauri, J. Palutikof, M. Parry, D. Qin, N. Ravindranath, A. Reisinger, J. Ren, K. Riahi, C. Rosenzweig, M, Rusticucci, S. SCHNeIder, Y. SOKONA, A. SOlOMON, P. STOTT, R. Stouffer, T. Sugiyama, R. Swart, D. Tirpak, C. VOGEL \& G. YOHE 2007. Climate change 2007: synthesis report. Cambridge: Cambridge University Press.

BINFORD, L.R. 1968. Archaeological perspectives, in S.R. Binford \& L.R. Binford (ed.) New perspectives in archaeology: 5-32. Chicago (IL): Aldine.

BurRoughs, W.J. 2005. Climate change in prehistory: the end of the reign of chaos. Cambridge: Cambridge University Press.

BUTZER, K. 1972. Environment and archaeology. London: Methuen.

Childe, V.G. 1958. Retrospect. Antiquity 32: 69-74.

CLARK, J.G.D. 1936. The Mesolithic settlement of northern Europe. Cambridge: Cambridge University Press.

Coles, B.J. 1998. Doggerland: a speculative survey. Proceedings of the Prehistoric Society 64: 45-82.

Council for British Archaeology. 2007. Adapting archaeology: foresight for climate change in the UK. Available at: http://www.britarch.ac.uk/ conservation/climate/adapting (accessed 13 January 2011).
Cox, P.M., R.A. BetTs, C.D. Jones, S.A. Spall \& I.J. TOTTERDELL. 2000. Acceleration of global warming due to carbon-cycle feedbacks in a coupled climate model. Nature 408: 184-7.

CRUMLEY, C.L. 1994. Historical ecology: cultural knowledge and changing landscapes. Santa Fe (NM): School of American Research.

DEMENOCAL, P.B. 2001. Cultural responses to climate change during the Late Holocene. Science 292: 667-73.

FAGAN, B. 2008. The great warming: climate change and the rise and fall of civilizations. New York: Bloomsbury.

FOLKE, C. 2006. Resilience: the emergence of a perspective for social-ecological systems analysis. Global Environmental Change 16: 253-67.

Gamble, C., W. Davies, P. Pettitt \& M. Richards. 2004. Climate change and evolving human diversity in Europe during the last glacial. Philosophical Transactions of the Royal Society B 359: 243-54.

HODDER, I. 1986. Reading the past: current approaches to interpretation in archaeology. Cambridge: Cambridge University Press.

- 1990. The domestication of Europe: structures and contingency in Neolithic Societies. Oxford: Blackwell.

Hodell, D.A., J.H. CurTis \& M. BrenNer. 1995. Possible role of climate in the collapse of Classic Maya civilization. Nature 375: 391-4.

Holling, C.S. 1973. Resilience and stability of ecological systems. Annual Review of Ecology and Sustainability 4: 1-23.

Hornborg, A. \& C.L. Crumley (ed.). 2007. The world system and the earth system: global socio-environmental change and sustainability since the Neolithic. Walnut Creek (CA): Left Coast Press.

Jansen, E., J. Overpeck, K.R. Briffa, J.-C. Duplessy, F. Joos, V. Masson-Delmotte, D. Olago, B. Otto-Bliesner, W.R. Peltier, S. Rahmstorf, R. Ramesh, D. Raynaud, D. Rind, O. Solomina, R. Villalba \& D. Zhang. 2007. Palaeoclimate, in S. Solomon, D. Qin, M. Manning, Z. Chen, M. Marquis, K.B. Averyt, M. Tignor \& H.L. Miller (ed.) Climate change 2007: the physical science basis. Contribution of Working Group I to the fourth assessment report of the Intergovernmental Panel on Climate Change. Cambridge: Cambridge University Press. 


\section{Conceptualising climate change archaeology}

Lotze, H.K., K. Reise, B. Worm, J. van BeuseKom, M. Busch, A. Ehlers, D. Heinrich, R.C. Hoffmann, P. Holm, C. Jensen, O.S. Knottnerus, N. Langhanki, W. Prummel, M. VOlLMer \& W.J. WolfF. 2005. Human transformations of the Wadden Sea ecosystem through time: a synthesis, in H.K. Lotze \& B. Reise (ed.) Ecological history of the Wadden Sea: 84-95. Helgoland: Helgoland Marine Research.

McAnaY, P. \& N. YoffeE (ed.). 2010. Questioning collapse: human resilience, ecological vulnerability and the aftermath of empire. Cambridge: Cambridge University Press.

McIntosh, R.J., J.A. TAInTER \& S.K. McIntosh. 2000. Climate, history and human action, in R.J. McIntosh, J.A. Tainter \& S.K. McIntosh (ed.) The way the wind blows: climate, history and human action: 1-42. New York: Columbia University Press.

MeIER, D. 2004. Man and environment in the marsh area of Schleswig-Holstein from Roman until late medieval times. Quaternary International 112: 55-69.

Mitchell, P. 2008. Practising archaeology at a time of climatic catastrophe. Antiquity 82: 1093-103.

Parry, M.L., O.F. Canziani, J.P. Palutikof, P.J. Van Der Linden \& C.E. Hanson (ed.). 2007. Climate change 2007: impacts, adaptation and vulnerability. Contribution of Working Group II to the fourth assessment report of the Intergovernmental Panel on Climate Change. Cambridge: Cambridge University Press.

RIPPON, S. 2000. The transformation of coastal wetlands: exploitation and management of marshland landscapes in North West Europe during the Roman and medieval periods. London: British Academy.

ROWLAND, M.J. 2010. Will the sky fall in? Global warming - an alternative view. Antiquity 84: 1163-71.

RudDiman, W. 2003. The anthropogenic greenhouse era began thousands of years ago. Climate Change 61: 261-93.

SCARRE, C. 2002. A pattern of islands: the Neolithic monuments of north-west Brittany. European Journal of Archaeology 5: 24-41.
Shennan, I. \& B. Horton. 2002. Holocene land and sea level changes in Great Britain. Journal of Quaternary Science 17: 511-26.

STERN, N. 2006. Stern review on the economics of climate change. London: HM Treasury; Cambridge: Cambridge University Press (2007).

TILley, C. 1994. A phenomenology of landscape: places, paths and monuments. London: Berg.

Trigger, B.G. 1996. A history of archaeological thought. Cambridge: Cambridge University Press.

Turney, C.S.M. \& H. Brown. 2007. Catastrophic early Holocene sea level rise, human migration and the Neolithic transition in Europe. Quaternary Science Reviews 26: 2036-41.

Turney, C.S.M., M. Baillie, J. Palmer \& D. Brown. 2006. Holocene climatic change and past Irish societal response. Journal of Archaeological Science 33: 34-8.

VAN DE NOORT, R. 2004. The Humber wetlands: the archaeology of a dynamic landscape. Bollington: Windgather Press.

- 2011. North Sea archaeologies; a maritime biography $10000 B C-A D$ 1500. Oxford: Oxford University Press.

VAN DER LeEuW, S. 2000. Land degradation as a socio-natural process, in R.J. McIntosh, J.A. Tainter \& S.K. McIntosh (ed.) The way the wind blows: climate, history and human action: 357-83. New York: Columbia University Press.

Weijerman, M., H. LindeboOm \& A.F. ZuUr. 2005. Regime shifts in marine ecosystems of the North Sea and Wadden Sea. Marine Ecology Progress Series 298: 21-39.

WhITE, L.A. 1959. The evolution of culture. New York: McGraw-Hill.

Yu, S., C. ZHU, J. Song \& W. Qu. 2000. Role of climate in the rise and fall of Neolithic cultures on the Yangtze Delta. Boreas 29: 157-65.

ZWART, H. 2003. Aquaphobia, tulipmania, biophilia: a moral geography of the Dutch landscape. Environmental Values 12: 107-128. 